Article

\title{
Investigations of the Surface of Heritage Objects and Green Bioremediation: Case Study of Artefacts from Maramureş, Romania
}

\author{
Dorina Camelia Ilieș ${ }^{1}$, Nicolaie Hodor ${ }^{2}$, Liliana Indrie ${ }^{3}$, Paula Dejeu ${ }^{4}$, Alexandru Ilieș ${ }^{1}$, Adina Albu ${ }^{3}$, \\ Tudor Caciora ${ }^{1, *(\mathbb{D})}$, Marin Ilies ${ }^{5}$, Lucian Barbu-Tudoran ${ }^{6,7}$ and Vasile Grama ${ }^{1}$ (D)
}

Citation: Ilieș, D.C.; Hodor, N.; Indrie, L.; Dejeu, P.; Ilieș, A.; Albu, A.; Caciora, T.; Ilieș, M.; Barbu-Tudoran, L.; Grama, V. Investigations of the Surface of Heritage Objects and Green Bioremediation: Case Study of Artefacts from Maramureş, Romania. Appl. Sci. 2021, 11, 6643. https:// doi.org/10.3390/app11146643

Academic Editors: Filomena De Leo and Daniela Isola

Received: 2 June 2021

Accepted: 14 July 2021

Published: 20 July 2021

Publisher's Note: MDPI stays neutral with regard to jurisdictional claims in published maps and institutional affiliations.

Copyright: (c) 2021 by the authors Licensee MDPI, Basel, Switzerland. This article is an open access article distributed under the terms and conditions of the Creative Commons Attribution (CC BY) license (https:// creativecommons.org/licenses/by/ $4.0 /)$
1 Department of Geography, Tourism and Territorial Planning, Faculty of Geography, Tourism and Sport, University of Oradea, 1 Universitatii Street, 410087 Oradea, Romania; dilies@uoradea.ro (D.C.I.); ailies@uoradea.ro (A.I.); vgrama@uoradea.ro (V.G.)

2 Faculty of Geography, "Babes-Bolyai” University, 5-6 Clinicilor, 400090 Cluj Napoca, Romania; nicolaie.hodor@ubbcluj.ro

3 Department of Textile, Leather and Industrial Management, Faculty of Energy Engineering and Industrial Management, University of Oradea, B. St. Delavrancea Str. No. 4, 410058 Oradea, Romania; lindrie@uoradea.ro (L.I.); aalbu@uoradea.ro (A.A.)

4 Medical Laboratory Service M.D., Bethany Medical Clinic, 410004 Oradea, Romania; office@betania-centrumedical.ro

5 Faculty of Geography Extension, "Babes-Bolyai” University, 6 Avram Iancu Street, 435500 Sighetu Marmatiei, Romania; marin.ilies@ubbcluj.ro

6 Electron Microscopy Laboratory 'Prof. C. Craciun', Faculty of Biology and Geology, “Babes-Bolyai" University, 5-7 Clinicilor Str., 400006 Cluj-Napoca, Romania; lucian.barbu@itim-cj.ro

7 Electron Microscopy Integrated Laboratory, National Institute for R\&D of Isotopic and Molecular Technologies, 67-103 Donat Str., 400293 Cluj-Napoca, Romania

* Correspondence: caciora.tudoriulian@student.uoradea.ro; Tel.: +40-740941144

Abstract: Old textiles are important elements of thecultural heritage. As a result of their composition mostly of natural elements old textiles are extremely prone to physical and chemical degradation due to fungal action. The treatments usually applied for the cleaning of heritage textiles target the use of synthetic fungicides, which are potentially harmful to both human health and the environment. Numerous studies highlight as an alternative to the use of conventional antifungals, the employment of essential oils and plant extracts, which are environmentally friendly and which have no adverse effects on human health. Against this background the present study aims to test six essential oils (Lavandula angustifolia, Citrus limon, Mentha piperita, Marjoram, Melaleuca alternifolia, Origanum vulgare) to establish their inhibitory effects against fungi identified on an old piece of traditional Romanian clothing from Maramureş. For the study, the types of fungi present on the objects was determined primarily through the open plates technique and microscopic identification. After identification, the essential oils were applied to the delimited surfaces, and their effects observed up to 32 days after application. The results show that these essential oils have a strong inhibitory effect on such fungal genera as Penicillinum sp., Cladosporium sp., Aspergillus spp., Candida guillermondii, Botrys sp., Mucor sp., having no observable side-effects on the physical properties of the materials concerned. The antimicrobial effects that essential oils and plant extracts have in the short term must be tested in future to ensure the enhanced preservation of heritage textiles and the health integrity of the restorers and visitors who view them in museums, collections or exhibitions.

Keywords: cultural heritage; materials; fungi; essential oils; antifungal; inhibitory effects

\section{Introduction}

The traditional folk costume from Maramures is an important component of the Romanian cultural heritage. Certain elements of the peasant's traditional garments are two thousand years old, as evidenced by the scenes on Trajan's Column in Rome, Italy 
(113 AC), those on the Monument to Adamclisi, Tropaeum Traiani (108-109 AC), from Dobruja, Romania and some other important archaeological discoveries from Romania. The preservation and conservation of popular traditional cloths is of great importance, especially now, when the modernisation of society and globalisation generate a growing standardization and lack of differentiation in the appearance of outfits [1,2], most especially those for men. While Maramureş celebration clothes still retain their former appearance, recently some materials and colours have come to be produced by relatively advanced and modernised techniques. The traditional objects are those most subject to degradation, due to the numerous insects, moths, fungi, bacteria and mechanical forces, among others, to which they are subjected over the years. At the same time traditional methods of preservation and conservation can be lost. Therefore, the preservation, in good condition, of the old components of traditional garments has acquired increasing importance, for the use, the identity and the pride of the future inhabitants of the region/country. Arguably, Maramures has become an identity brand, symbolising the art and the creative power, as well as the youth, vigour and elegance of the Romanian inhabitants of Maramures.

Under investigation is an aged garment object which is mainly made up of natural sheep's wool; for the popular motifs that adorn it materials as sheepskin, cotton yarn, pearly beads and hemp yarn also are used. All of these materials are organic, undergoing chemical processing to give them a long life, stability and elasticity, if they are stored and used properly. Historically, the causes of damage to natural materials vary over time. Biological damage is a factor that makes the leather and furs particularly vulnerable. Due to the acidity of the skin under conditions of high humidity, the development potential for colonies of microorganisms is very high, with them adhering to the substrate along with dust particles and other environmental substances. Furs and wool can be attacked by insects such as moth larvae, beetles and others, and specific microclimatic conditions, characterised by conditions of high humidity, low intensity of light and others, favour their multiplication. Bio-damage can lead, in time, to the complete destruction of the object. Physical and chemical damage is caused by natural factors, with chemical damage being faster than physical damage, with the former's effects being profound and irreversible [3]. Deterioration can be caused by natural factors [4]. Temperature levels can pose problems that are difficult to solve in relation to the conservation of collections if favouring the development of moulds (along with high humidity), along with insects and rodents, and accelerating chemical damage to materials. The amount of damage incurred is increased when the materials are present in a relative humidity below $50 \%$, under which conditions they tend to become dry and brittle, and their physical strength decreases. At high humidity or on contact with aqueous solutions, the collagen present is destroyed, with negative effects occurring in terms of destruction of the structure and an increase in the hydrophilicity of the fibres involved. Light, due to photochemical effects, can also cause significant degradation, in terms of the weakening of the resistance of the material substrate, friability, chromatic changes, rupture of collagen fibres and others. Ultraviolet light should be removed without affecting the lighting concerned. The presence of dust promotes biological attacks on the skin and furs. Damage to the objects due to anthropogenic causes can also occur, as a result of improper storage and exposure (e.g., materials being placed directly on top of one another, wrinkled, placed in contact with metal objects, fixed with needles and/or nails, the improper affixing of labels among others) $[5,6]$.

Under certain environmental conditions the colonization of microorganisms is possible with the combination of factors including: temperature, humidity fluctuation, natural or artificial lighting (favorable premises for the installation and evolution of microorganisms are improper exposure to sunlight and weather [7-9], dust content and carbon dioxide high values or when nutrients are favorable); these can induce very frequent biodeterioration, alteration processes [10-12]. Wool fibers are most susceptible to attack by bacteria and fungi, especially in conditions where moisture can be accentuated due to the hygroscopic properties of wool. The microorganisms most frequently [13] mentioned in degradation of wool and other protein fibers are bacteria which belongs to the genus: 
Bacillus, Proteus, Actinomycetes (Streptomyces sp.) and micro-fungi: Aspergillus, Fusarium and Trichoderma, Penicillium.

The biodeteriogens represented by fungi can lead to the deterioration of the cultural heritage organic composition materials, with their hyphae penetrating the substrate material favouring the germination of spores. The possible physical damage is likely to be colouring/discoloration, the smell of mould, fissures, fragment detachments, fragility and the variation of dyeing properties, among others [13-17]. Possible chemical damage and changes can be wrought by fungal-derived carboxylic acids, including oxalic, citric, succinic, formic, malic, acetic, fumaric and others. In addition, chemical changes can also be reflected in aesthetical damages to the cultural materials concerned, such as in the form of the discoloration and deterioration of the surfaces involved, leading to the appearance of stains that may alter the original colour of the garment [18-21]. The presence of organic residues (e.g., glue, dirt, dust) may accelerate the processes of degradation, with the aesthetical changes and chromatic alteration taking place. At the same time, they can lead to the loss of strength and elongation specific to the material, oxidation, discoloration or coloration, due to the pigments involved and the modification of the molecular structures present [22].

Remediation can be realised using toxic materials (e.g., ethylene oxide [EtO], gamma rays, etc.), but the use of such materials can significantly affect the biodiversity and ecological systems concerned. Therefore, specialists in the field try to apply environmentally and ecologically friendly biocides instead. The use of antifungal natural extracts (i.e., essential oils [EOs]) has always been a viable alternative to the use of harmful chemicals, with, for example, plant extracts (Allium ursinum and Ocimum basilicum) having been tested as successful antifungals [23].

EOs (e.g., lemon, spearmint, rosemary, fennel, marjoram, pin, eucalyptus, etc.) can successfully serve as part of a green bioremediation procedure to be applied in the sustainable conservation of artworks. Having been tested against microbial colonies isolated from different substrates using green potential strategies, they have been found to act as a sound alternative to traditional procedures in terms of their selective action, human safety and impacts on artworks [20,24-41]. The antifungal activity of Origanum vulgare, Rosmarinus officinalis and Lavandula angustifolia EOs has been tested, with positive results having been achieved against fungi isolated on stone (Bipolaris sp.) and against Aspergillus sp., Penicillium sp., and Trichoderma sp. on different objects by Stupar et al. [42], Savković et al. [43] and Bayramoğlu [44], among others. Some relevant studies in the field [45-50] confirm that thymus EO has been found to have good antimicrobial activity against Bacillus, Staphylococcus, Fusarium and Aspergillus spp., in comparison to the effects of EO with commercial biocide. Radwan et al. [49] point out the inhibitory effect of thyme, clove and cinnamon EOs on Candida albicans and different finds of mould. The EOs of eucalyptus and lavender tested with good results as natural preservatives for leather [51], with oregano EO being successfully used as a bactericidal agent in the leather industry by Bayramoğlu et al. [26,44]. Combinations of the EOs [52], Thymus vulgaris and Pimpinella anisum and methanol extracts, have shown outstanding antibacterial properties against the pathogenic bacteria, Staphylococcus aureus, Bacillus cereus, Escherichia coli, Proteus vulgaris, Proteus mirabilis, Salmonella typhi, Salmonella typhimurium, Klebsiella pneumoniae and Pseudomonas aeruginosa. EOs obtained from Matricaria chamomilla have been tested [53] as environmentally friendly in cultural heritage environments, against Aspergillus spp.; similarly, Mahilrajan et al. [54] pinpoint in the same study, the intense antifungal activity of camphor oil, in comparison with other tested oils. Pepa et al. [55] point out that EOs from southern Italy, derived from Origanum, tested with the minimal inhibitory concentrations, in vitro, with evident antibacterial and antifungal activity. EOs like Origanum vulgare and Thymus vulgaris have also been applied by Palla et al. [56] to emphasise the green remediation in the biodeterioration of cultural heritage artworks, which is induced by fungal colonisation (e.g., by that of Aspergillus flavus). The above-mentioned authors concluded that valid green conservation strategies 
(with no negative effects for human health and no environmental pollution) could possibly replace traditional biocides.

In Romania, recently, an EO isolated from thyme (Thymus vulgaris) was assayed for antifungal activity against Candida albicans and Aspergillus niger on sheepskins, with it being shown to have outstanding antifungal proprieties [57-59]. Moreover, the studies by Niculescu et al. [60,61] and Marcu et al. [62] have emphasised the possibility of using antifungal ecological materials to treat cultural heritage objects made of natural leather.

Following the above, this research aimed to investigate the microbial load of an old heritage object, made of natural animal sheepskin, which metabolic activity could generate, thus accelerating the biodegradation process, and the loading of the aerosol with biological particles, like spores, toxins and allergens, as well as other harmful substances. Such action can cause problems regarding the health of workers and users and the application of natural biodegraders. Consequently, the antifungal properties of some EOs of Lavandula angustifolia, Citrus limon, Mentha piperita, Marjoram, Melaleuca alternifolia, Origanum vulgare were tested, with the results of their applications being recorded at certain time intervals.

\section{Materials and Methods}

\subsection{Investigated Object}

The object investigated was a handmade, short coat for young men, lined with sheepskin from the Mara Valley, Maramureș, Romania (Figure 1) [63-66], about 80 to 100 years old. The men's garment was created to cover the torso, with it being worn most often on important holidays or on Sundays.
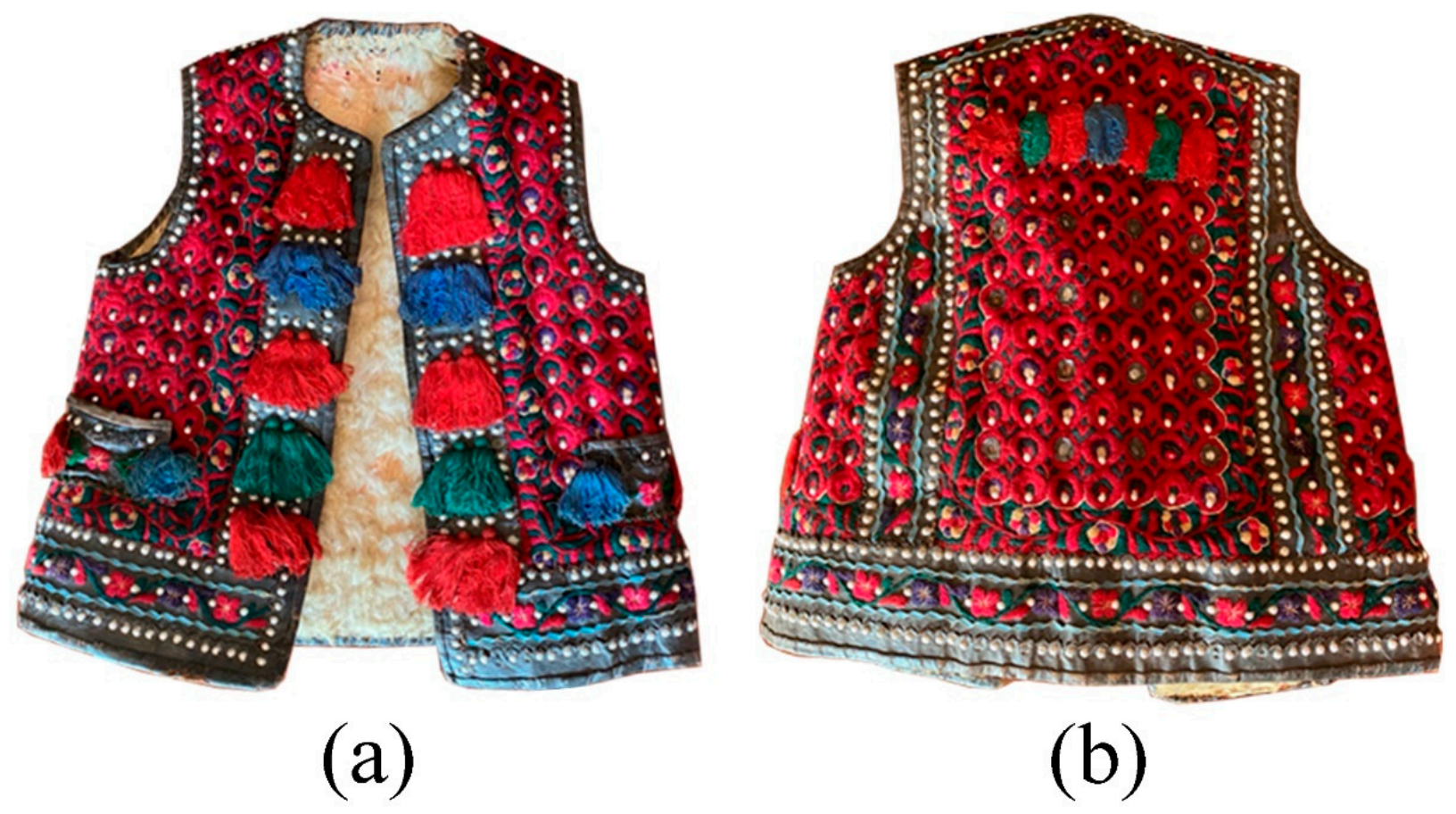

Figure 1. Traditional Romanian men's coat; (a)—front view; (b)—back view.

The coat was made of hemp thread (also called 'pânză de tort' in Romanian). The coat's lining consisted of sewn tanned lambskin, of curly wool. On all its edges and at the seams, an intensely dark-hued strip ('cipcă') or hem of red leather was applied, conveying a sense of perfect regularity and symmetry. On the inside, there was a large pocket on the left side, facilitating access by the right hand. The coat was decorated by hand-sewing (similar to embroidery), with coloured thread, and by applying decorative elements made of tanned leather, over the whole bridge of the coat, consisting of the tree of life, rose flowers called ' $r u j i$ ', stitched flowers encircling mirrors and pseudo zig-zag patterning. In the middle 
of some rose flowers without mirrors, special metal buttons ('bumbi') had been placed, rounded and extended, with some fasteners facing inwards, which helped to affix them to the fabric structure, by means of their being bent. Near the free edge of the wings and on the back of the coat, close to the shoulders are several ornamental tassels (bell-shaped tassels) arranged symmetrically, in red, green and blue colours.

In the last half century, other examples of such fur coats (from Mara) have begun to be worn in other parts of Maramures, becoming an identity brand [67-70], symbolising the art and creative power of the youth, as well as the vigour and elegance of the Romanians in Maramureș.

\subsection{Analytical Methods}

The procedure followed in the current study required the following materials: a delimiting frame; sterile swabs on a wooden rod; and six EOs with $100 \%$ purity from the Young Living Essential Oils, used for their antifungal properties [71-79]. The types of EOs employed were: Mentha piperita, Lavandula angustifolia, Citrus limon, Melaleuca alternifolia, Marjoram and Origanum vulgare. The products used consisted of: Mentha piperita, batch 103519, expiry date 7 August 2021; Lavandula angustifolia, batch 87491, expiry date 7 August 2021; Citrus limon, batch 103517, expiry date 7 August 2021; Tea Tree, batch 89075, expiry date October 2021; Marjoram, batch 86942, expiry date July 2022; and Oregano, batch 89094, expiry date September 2022. The material resources used consisted of: Sabouraud sterile culture medium for the yeast and mould isolation; an incubator ICT 18/FALC with a temperature range between 5 and $80^{\circ} \mathrm{C}$; a microbiological hood; glass slides and slides for the microscopic identification; microbiological handles; an optical microscope Micros Austria with binocular head series BIM-105B; an API yeast identification kit ${ }^{\circledR \circledast} 20$ C AUX; and a densitometer.

Six different areas on the face of the traditional coat were examined, as shown in Figure 2. The working areas were delimited by means of a metal dial with a size of $25 \mathrm{~cm}^{2}$. Small fragments (millimetres) of fur and sheepskin were removed with tweezers previously sterilized by the incandescent method for testing of the fungi concerned; so as to observe the effects that they might have had on the individual strands of material. The tests were conducted both before and after applying the EOs to each delimited area, although the primary samples were considered as blank references.

After delimiting the surfaces on which the in-situ procedures were to be performed, the samples of the surface were taken. The samples were extracted using sterile swabs from all six areas of the sheepskin coat, both before and after the application of the Eos (see Table 1). Ten drops (the equivalent to $300 \mu \mathrm{L}$ ) of the corresponding EO were applied directly to the tested material surface in the centre of each delimited area [75]. After the application of the EOs, three samples were taken for each of the six different work areas delimited on the area of sheepskin to which the EOs were applied. The three samples were taken at pre-set intervals, with the first sample being taken $30 \mathrm{~min}$ after the administration of the EOs, the second test being administered after $24 \mathrm{~h}$ and the third after $48 \mathrm{~h}$. Table 1 also shows the type of material examined and the type of EO applied to each of the delimited areas. The EO used for each type of material concerned was selected in accordance with the recommendations made in the literature, especially that of Palla et al. [56], which state that certain EOs tend to be more effective than others when applied to certain types of material, such as those which constitute heritage objects.

It must be noted that the air in the room in which the sheepskin coat was stored and examined was not circulated, and neither was the room ventilated for $48 \mathrm{~h}$ during the entire examination, so as to avoid contamination with other types of spores from the atmosphere that could, otherwise, have been introduced by currents of air moving through the room. The temperature was maintained between $22{ }^{\circ} \mathrm{C}$ and $24{ }^{\circ} \mathrm{C}$, while the humidity was kept between $52 \%$ and $55 \%$. 

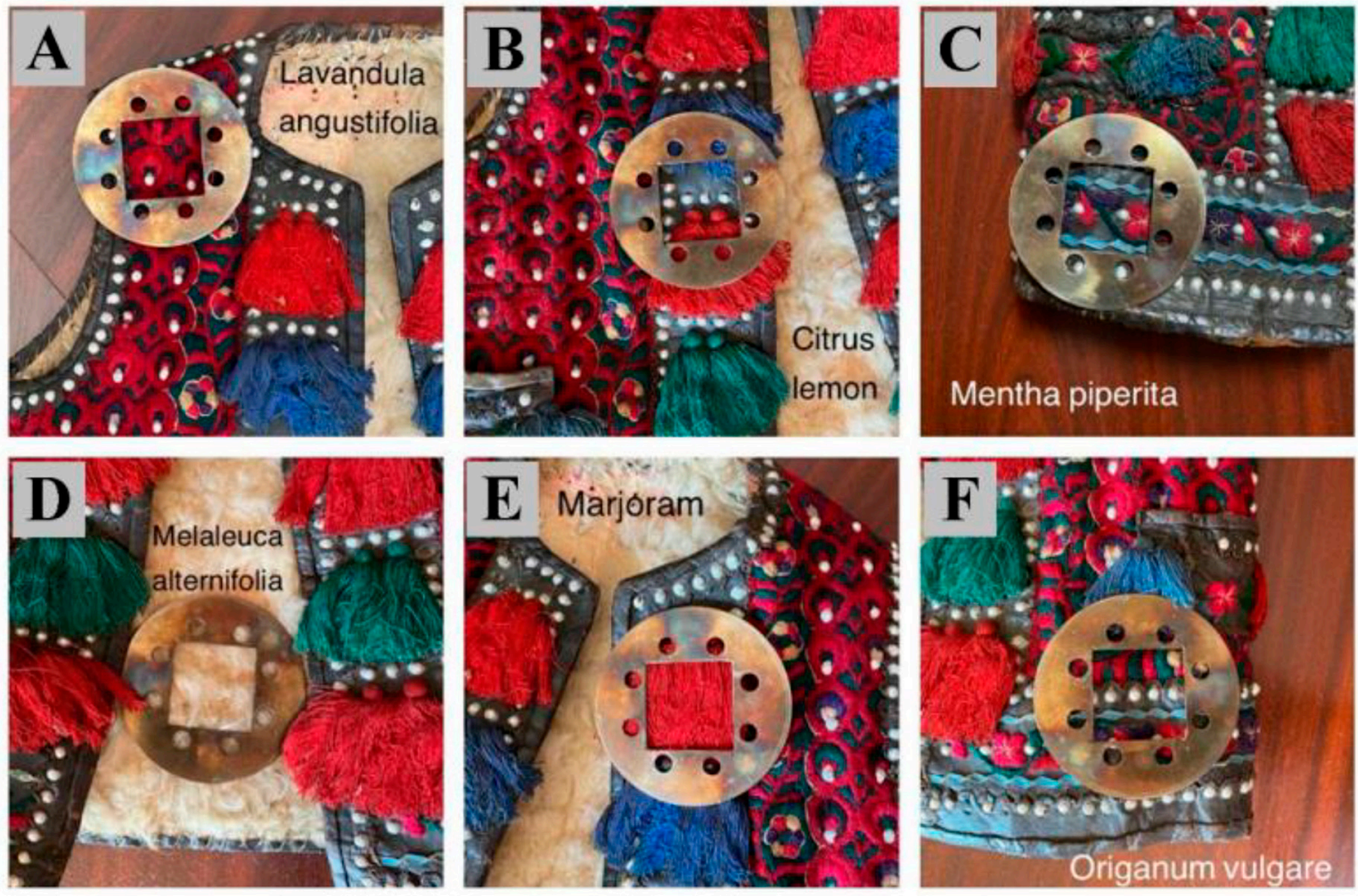

Figure 2. Delimitation of the six work areas on the front of the coat, indicating the type of essential oil applied to each (A)—Lavandula angustifolia; (B)—Cistrus lemon; (C)—Mentha piperita; (D)—Melaleuca alternifolia; (E)—Marjoram; (F)— Origanum vulgare.

Table 1. Areas of the sheepskin coat examined, and to which essential oils applied.

\begin{tabular}{ccc}
\hline Examined Area (Figure 2) & Applied Essential Oil & Material Type \\
\hline A & Lavandula angustifolia (lavender) & Cotton yarn \\
B & Citrus limon (limon) & Leather-cotton yarn mix \\
C & Mentha piperita (mint) & Leather \\
D & Melaleuca alternifolia (tea tree) & Wool \\
E & Marjoram (marjoram) & Cotton yarn \\
F & Origanum vulgare (oregano) & Pearly beads \\
\hline
\end{tabular}

With the EOs having been applied directly to the examined surfaces, all the samples were seeded on sterile Sabouraud culture media, with the plates used being incubated for 30 days at a temperature of $28^{\circ} \mathrm{C}$. The third stage of the procedure involved isolating and identifying the fungi developed on culture media. The plates were evaluated daily to observe their evolution in terms of the changes in the appearance of the colonies concerned, with the evaluation undertaken sequentially being that of shape, texture, consistency, diameter, colour and contour.

The moulds present were identified after evaluating the macroscopic and microscopic characteristics involved, and the yeast species was determined, using the API ${ }^{\circledR} 20{ }^{\circ} \mathrm{C}$ AUX6 identification kit, after examination of the 19 biochemical assimilation reactions that took place. The technique of working on the latter involved preparing the yeast suspension solution, calibrated at $2 \mathrm{McF}$ arland, using a densitometer, and thereafter pipetting $100 \mu \mathrm{L}$ into each microdwell of the gallery. After incubating the API gallery at $29^{\circ} \mathrm{C} \pm 2{ }^{\circ} \mathrm{C}$ for $72 \mathrm{~h}$, the results were read, with a final result being obtained after comparing each well with the negative control. The final result was a 7-digit numerical profile, which was decoded using Apiweb ${ }^{\mathrm{TM}}$ computer software, so as to identify the corresponding yeast species. 


\section{Results}

Fungal colonies were developed rapidly on Sabouraud media, from samples taken before the application of EOs. At $72 \mathrm{~h}$ of incubation, the first fungal colonies could be macroscopically visualised. After 10 days of incubation, the plates were completely invaded. Figure 3 shows the plates on the seventh day of incubation; each image indicates the examined area of the sheepskin coat. The high degree of fungal contamination of the coat can easily be observed.

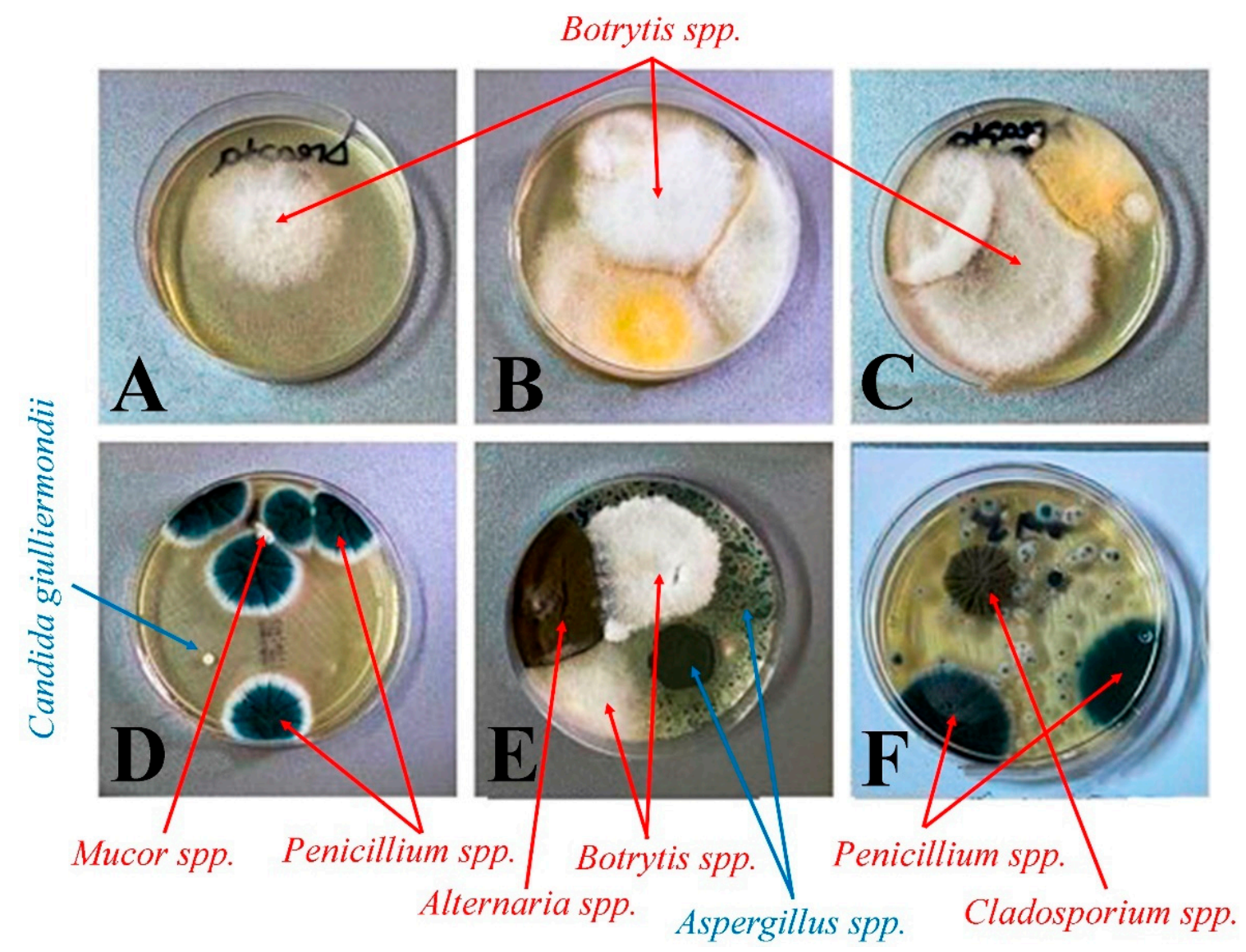

Figure 3. Plates seeded with primary samples (before application of essential oils). Reading taken after 7 days of incubation (A)—Lavandula angustifolia; (B)—Cistrus lemon; (C)—Mentha piperita; (D)—Melaleuca alternifolia; (E)—Marjoram; (F)-Origanum vulgare.

In the above-mentioned way, seven different types of colonies were identified [80,81], with six being from the mould class (Alternaria sp., Aspergillus sp., Botrytis sp., Cladosporium sp., Mucor sp. and Penicillium sp.) and one from the yeast class (Candida guilliermondii) (Table 2).

As previously stated the number of samples taken after applying the EOs was 3 sets of 6, taken $30 \mathrm{~min}, 24 \mathrm{~h}$ and $48 \mathrm{~h}$ after applying the corresponding EO. The plates were monitored for 30 days in order to evaluate the inhibitory effects of the EOs. Figure 4 shows the plates, as read on day 14 of the incubation. The inhibitory effects of the EOs are evident. The only plate on which a fungal colony developed is the one corresponding to the inner area of the sheepskin coat, present in the sample taken $48 \mathrm{~h}$ after applying the EO of Melaleuca alternifolia (tea tree). The isolated fungal colony consisted of Cladosporium sp., which became macroscopically visible on day 5 of incubation. It was observed that this type of mould was not isolated from the primary sample, as is detailed in the discussion section below. 
Table 2. Identified fungi and the effect of essential oils.

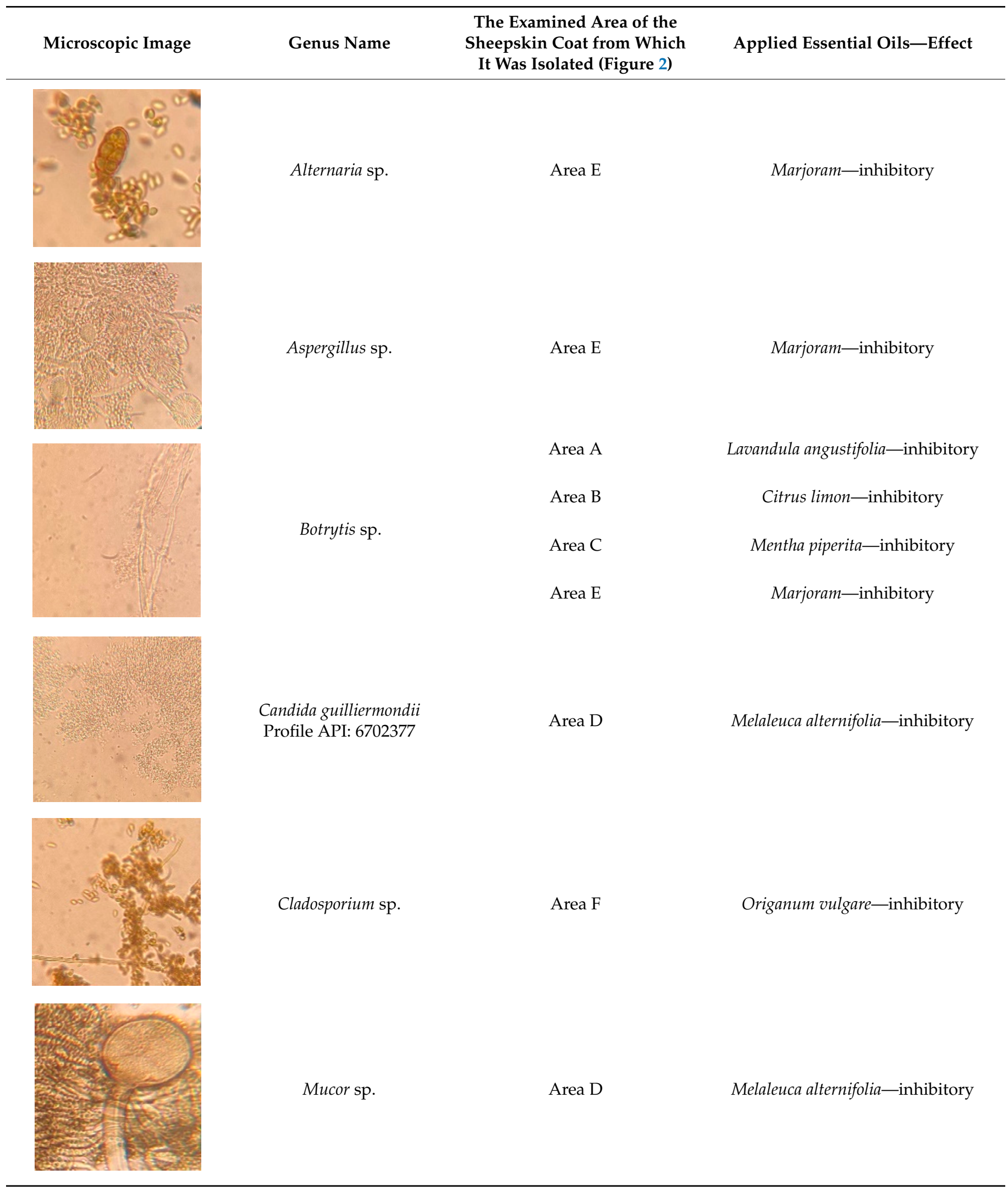


Table 2. Cont.

\begin{tabular}{cccc}
\hline Microscopic Image & Genus Name & $\begin{array}{c}\text { The Examined Area of the } \\
\text { Sheepskin Coat from Which } \\
\text { It Was Isolated (Figure 2) }\end{array}$ & Applied Essential Oils-Effect \\
\hline & Penicillium sp. & Area D & $\begin{array}{c}\text { Melaleuca alternifolia—inhibitory } \\
\text { Origanum vulgare-inhibitory }\end{array}$ \\
\hline
\end{tabular}

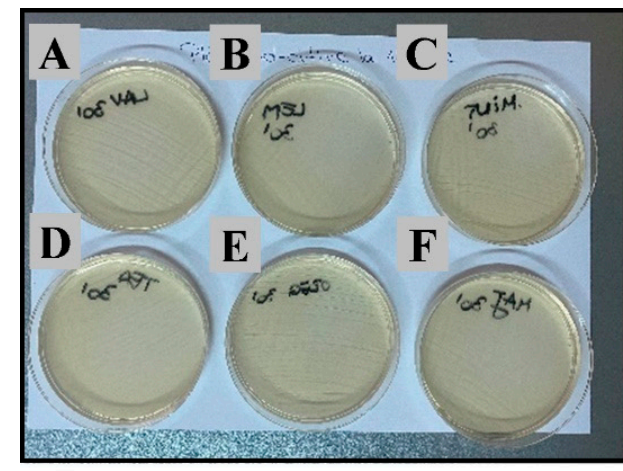

(a)

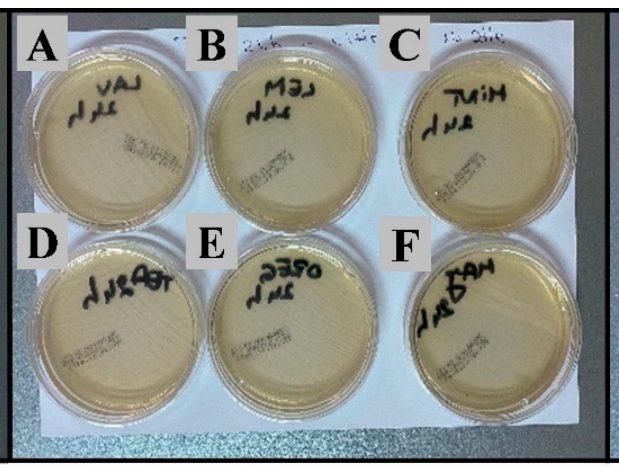

(b)

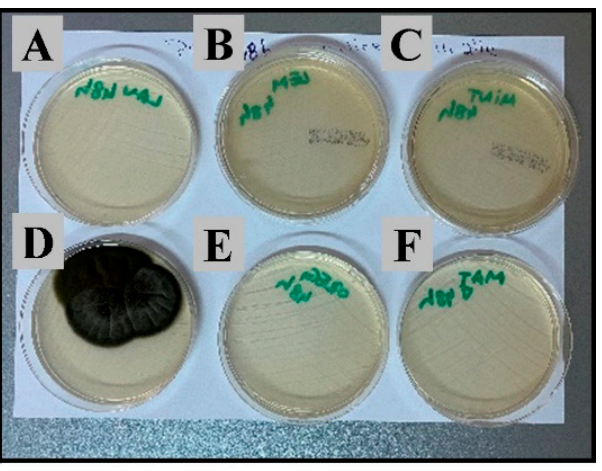

(c)

Figure 4. The plates read on day 14 of incubation: the samples at (a) $30 \mathrm{~min}$, (b) $24 \mathrm{~h}$ and (c) $48 \mathrm{~h}$.

Figure $5 \mathrm{a}-\mathrm{c}$ show the plates, as read on day 30 of the incubation. The developed colonies became macroscopically visible after between 20 days to 25 days of incubation.

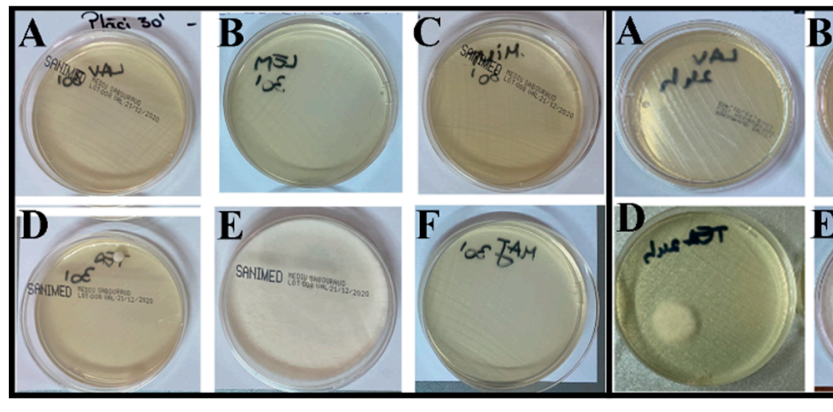

(a)

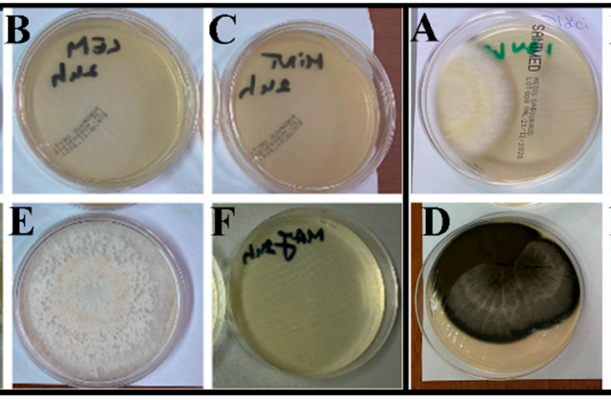

(b)

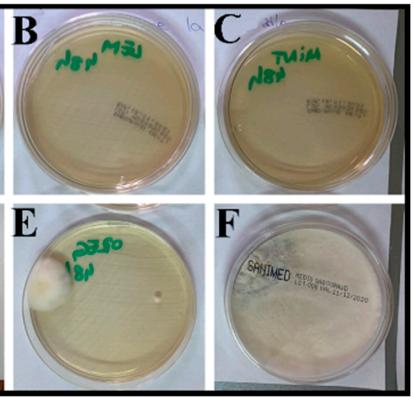

(c)

Figure 5. The plates read on day 30 of incubation: samples at (a) $30 \mathrm{~min}$, (b) $24 \mathrm{~h}$ and (c) $48 \mathrm{~h}$.

The results, obtained after the samples from the examined areas were examinedat $30 \mathrm{~min}, 24 \mathrm{~h}$ and $48 \mathrm{~h}$ following the application of the EOs, are presented in Table 3.

The existing difference was due to the duration of the effect that they had on certain types of fungi as shown on Table 4. It is evident that some EOs (e.g., Lavandula angustifolia, Melaleuca alternifolia, Marjoram, Origanum vulgare) inhibited the action of some fungal genera up to a period of 22 days, whereas on others the effect lasted for a period of at least 30 to 32 days (Table 4 ). 
Table 3. Interpretation of the seeded plates, with samples taken $30 \mathrm{~min}, 24 \mathrm{~h}$ and $48 \mathrm{~h}$ after applying the essential oil.

\begin{tabular}{|c|c|c|c|}
\hline Samples Taken & Examined Area & Essential Oil & Fungal Colony Growth \\
\hline \multirow{6}{*}{30 min after application of the essential oils } & Area A & Lavandula angustifolia & Absent \\
\hline & Area B & Citrus limon & Absent \\
\hline & Area C & Mentha piperita & Absent \\
\hline & Area D & Melaleuca alternifolia & Mucor sp. \\
\hline & Area E & Marjoram & Absent \\
\hline & Area F & Origanum vulgare & Botrytis sp. \\
\hline \multirow{6}{*}{$24 \mathrm{~h}$ after the application of the essential oils } & Area A & Lavandula angustifolia & Absent \\
\hline & Area B & Citrus limon & Absent \\
\hline & Area $C$ & Mentha piperita & Absent \\
\hline & Area D & Melaleuca alternifolia & Mucor sp. \\
\hline & Area E & Marjoram & Absent \\
\hline & Area F & Origanum vulgare & Botrytis sp. \\
\hline \multirow{6}{*}{$48 \mathrm{~h}$ after the application of the essential oils } & Area A & Lavandula angustifolia & Botrytis sp. \\
\hline & Area B & Citrus limon & Absent \\
\hline & Area C & Mentha piperita & Absent \\
\hline & Area D & Melaleuca alternifolia & Cladosporium sp. \\
\hline & Area E & Marjoram & Botrytis sp. \\
\hline & Area F & Origanum vulgare & $\begin{array}{l}\text { Cladosporium sp. } \\
\text { Botrytis sp. }\end{array}$ \\
\hline
\end{tabular}

Table 4. Fungal species inhibited by tested essential oils and the tested duration of their inhibitory effect.

\begin{tabular}{|c|c|c|}
\hline Essential Oil Used & Inhibited Fungal Species & Duration of the Inhibitory Effect from the Moment of Application \\
\hline Lavandula angustifolia & Botrytis sp. & Up to 22 days \\
\hline Citrus limon & Botrytis sp. & Minimum of 32 days \\
\hline Mentha piperita & Botrytis sp. & Minimum of 32 days \\
\hline Melaleuca alternifolia & $\begin{array}{c}\text { Candida guilliermondii } \\
\text { Mucor sp. } \\
\text { Penicillium } \mathrm{sp} .\end{array}$ & $\begin{array}{l}\text { Minimum of } 32 \text { days } \\
\text { Up to } 22 \text { days } \\
\text { Minimum of } 30 \text { days }\end{array}$ \\
\hline Marjoram & $\begin{array}{l}\text { Alternaria sp. } \\
\text { Aspergillus sp. } \\
\text { Botrytis sp. }\end{array}$ & $\begin{array}{l}\text { Minimum of } 30 \text { days } \\
\text { Minimum of } 30 \text { days } \\
\text { Up to } 22 \text { days }\end{array}$ \\
\hline Origanum vulgare & $\begin{array}{l}\text { Cladosporium sp. } \\
\text { Botrytis sp. } \\
\text { Penicillium sp. }\end{array}$ & $\begin{array}{l}\text { Minimum of } 30 \text { days } \\
\text { Up to } 22 \text { days } \\
\text { Minimum of } 30 \text { days }\end{array}$ \\
\hline
\end{tabular}

\section{Discussion}

After the tests were performed on the delimited surfaces of the 80- to 100-year-old clothing object, the conclusion was drawn that all the EOs had a strong inhibitory effect on the fungi present, even if they were applied on different materials (cotton yard, leather, wool, pearly beads). This is due to the fungicidal effect of EOs, which persists in some cases over 30 days after application. Similar results were obtained by different authors [82-85] following the application of these extracts on various materials. Most EOs (except for Citrus limon and Mentha piperita) were observed to have relatively little effect on Botrytis sp., which might indicate some resistance of this type of fungus to the action of the substances concerned.

It was revealed that the genus Cladosporium sp. developed at 5 days of incubation on the culture medium shown with the sample taken $48 \mathrm{~h}$ after the application of the EO, without the species involved having been isolated from the primary sample (taken before the application of the EO). The sample concerned was taken from the wool threads of the inner region of the coat. Woollen garments seem to be easily contaminated with fungal spores, with the degree of fungal contamination being most likely to differ from layer to 
layer-superficial, intermediate and basal. The spores that are present in the lower layers may rise to the surface over time, and, if the EO is applied superficially or in insufficient quantity, its inhibitory effect is diminished. Moreover, in the case of studies like the present, the environmental conditions present in the room (temperature, humidity, air currents) must be taken into account, as well as the sampling procedure itself. All such factors form a set of features that can interfere with the final results.

The fungal action identified on the garment investigated could be pathological for humans, especially for the personnel handling the garment. Although the fungi of the Aspergillus spp. family are generally harmless, they can cause various pathologies in those with compromised immune systems, underlying lung disease or asthma, who inhale the relevant fungal spores. The pathologies resulting from infections with such a fungus, which usually affect the respiratory system, have greatly varying signs and severity. In some (such as asthmatics), the spores trigger an allergic reaction, whereas others tend to develop mild to severe lung infections. The most serious form of aspergillosis, invasive aspergillosis, occurs when the infection spreads through the blood vessels, with the signs and symptoms of the infection varying, depending on the type of pathology that the patients concerned develop, and with it not being contagious. Daily exposure to Aspergillus is rarely a problem for people with healthy immune systems [86-88]. Fungi from the Candida guilliermondii family appear to be one of the most common pathogens in localised infections of the nails (onychomycosis) and/or of the skin on the toes. In patients with low immunity, infections with such a fungus can be a potential cause of fungal infections in the blood, namely fungemia, especially in patients with haematological malignancies, organ transplants and central venous catheters. This type of fungus is one of the most common opportunistic agents in severely immunocompromised patients. In such cases, depending on the associated pathologies, fungemia can prove fatal [89]. Fungal infections of the Cladosporium spp. family either aggravate the symptoms of an existing asthma, or are associated with atopy located mainly in the upper respiratory tract (allergic rhinitis/sinusitis) and less often in the skin (superficial or deep skin lesions). The impact of patients' symptoms (dyspnoea, sneezing, stuffy nose, pruritus, nasal/ocular secretions) was significantly correlated with spore concentrations. In patients with weakened immune systems, infections with this type of fungus can even cause disseminated infections, called fungemia [90-92]. Fungi of the genus Penicillium spp., which are occasionally the cause of infection in humans, can be isolated from patients with keratitis, endophthalmitis, otomycosis, necrotising esophagitis, pneumonia, endocarditis, peritonitis and urinary tract infections. Most Penicillium infections occur in immunosuppressed hosts, and the mechanism of infection with this type of fungus is either by means of inhalation (most commonly resulting in fungemia) or post-traumatic $[93,94]$.

\section{Conclusions}

The clothing objects that make up the cultural heritage are prone to deterioration, due to fungal action, especially if they are stored or exposed in environments that lack careful adjustment of the internal microclimate parameters. In addition to the harmful effects that fungi can have on heritage objects, people (restorers, museographers, collectors, visitors) who come in contact with such infested objects can develop specific conditions. Thus, treating historical textiles in the most responsible way possible becomes a dual purpose issue; on the one hand, it is necessary to preserve the materials under the best possible conditions, and, on the other hand, it is necessary to ensure the integrity of the health of those who are interested in them. The current study demonstrates that EOs are one of the most viable solutions to help ensure responsible treatment given that their antifungal properties can exceed 30 days of use, and with the products being both ecofriendly and accessible in terms of cost. The six EOs (Lavandula angustifolia, Citrus limon, Mentha piperita, Melaleuca alternifolia, Marjoram, Origanum vulgare) applied on different types of materials served to inhibit the presence of six different fungal colonies (Alternaria sp., Aspergillus sp., Botrytis sp., Cladosporium sp., Mucor sp. and Penicillium sp.) and a class of yeast (Candida 
guilliermondii) identified as being on the traditional coat. Simultaneously, the EOs had a strong antifungal effect on several materials (cotton, leather, wool) that formed part of the object investigated. Thus, all of the products studied were proven to be effective on certain surfaces and against certain types of fungi, in terms of both their cleaning and their protection effects. Prospects for the future must include the use of natural antifungals for the treatment of heritage objects; but at the same time, the tests must also aim at determining the possible negative effects that they may have on fragile objects.

Author Contributions: Conceptualisation: D.C.I. and N.H.; Methodology: P.D. and L.I.; Software: L.B.-T. and A.A.; Validation: P.D. and A.A.; Formal analysis: P.D., L.I. and L.B.-T.; Investigation: P.D., A.I. and M.I.; Resources: L.I. and A.A.; Data curation: P.D., D.C.I., N.H. and T.C.; Writing-original draft preparation: D.C.I., P.D., M.I. and T.C.; Writing-review and editing: D.C.I., T.C., A.I., M.I. and V.G. All authors have read and agreed to the published version of the manuscript.

Funding: This research was funded by grant PN-III-P1-1.2-PCCDI-2017-0686.

Institutional Review Board Statement: Not applicable.

Informed Consent Statement: Not applicable.

Data Availability Statement: The data presented in this study may be obtained on request from the corresponding author.

Acknowledgments: The research undertaken was made possible by the equal scientific involvement of all the authors concerned. The authors wish to thank the anonymous reviewers for their thoughtful suggestions and comments made, and to acknowledge the support of the grant PN-III-P1-1.2-PCCDI2017-0686. The investigations and analyses involved were done at the Medical Laboratory Service M.D., Bethany Medical Clinic Oradea, University of Medicine and Pharmacy of University of Oradea and at the National Institute of Research-Development for Isotopic and Molecular Technologies, Cluj-Napoca.

Conflicts of Interest: The authors declare no conflict of interest.

\section{References}

1. Albu, A.V.; Caciora, T.; Berdenov, Z.; Ilies, D.C.; Sturzu, B.; Sopota, D.; Herman, G.V.; Ilies, A.; Kecse, G.; Ghergheles, C.G. Digitalization of garment in the context of circular economy. Ind. Text. 2021, 72, 102-107. [CrossRef]

2. Ilies, D.C.; Herman, G.V.; Caciora, T.; Ilies, A.; Indrie, L.; Wendt, J.A.; Axinte, A.; Diombera, M.; Lite, C.; Berdenov, Z.; et al. Considerations Regarding the Research for the Conservation of Heritage Textiles in Romania. In Waste in Textile and Leather Sectors; Körlü, A., Ed.; IntechOpen: Rijeka, Croatia, 2020; Chapter 10; pp. 88-93.

3. Cappitelli, F.; Cattò, C.; Villa, F. The Control of Cultural Heritage Microbial Deterioration. Microorganisms 2020, 8, 1542. [CrossRef]

4. Indrie, L.; Oana, D.; Ilies, M.; Ilies, D.C.; Lincu, A.; Ilies, A.; Baias, S.; Herman, G.; Onet, A.; Costea, M.; et al. Indoor air quality of museums and conservation of textiles art works. Case study: Salacea Museum House, Romania. Ind. Text. 2019, 70, 88-93. [CrossRef]

5. Creangã, D.M. Cauzele degradarii bunurilor de patrimoniu pe suport de piele. Codrul Cosm. 2004, 10, $153-157$.

6. Di Carlo, E.; Chisesi, R.; Barresi, G.; Barbaro, S.; Lombardo, G.; Rotolo, V.; Sebastianelli, M.; Travagliato, G.; Palla, F. Fungi and Bacteria in Indoor Cultural Heritage Environments: Microbial-related Risks for Artworks and Human Health. Environ. Ecol. Res. 2016, 4, 257-264. [CrossRef]

7. Jain, P.C. Microbial Degradation of Grains, Oil Seeds, Textiles, Wood, Corrosion of Metals and Bioleaching of Mineral Ores; Department of Applied Microbiology \& Biotechnology, Dr. Harisingh Gour University: Sagar, India, 2008; Available online: http:/ /awarticles.s3 .amazonaws.com/PCJain2008MicrobialDegradationOfGrainsOilSeeds.pdf (accessed on 1 September 2020).

8. De Leoa, F.; Urzì, C. Microfungi from Deteriorated Materials of Cultural Heritage. In Fungi from Different Substrates; Misra, J.K., Tewari, J.P., Deshmukh, S.K., Vagvolgyi, S., Eds.; Taylor and Francis Press: Abingdon, UK, 2015; pp. $144-158$.

9. Kavkler, K.; Gunde-Cimerman, N.; Zalar, P.; Demsar, A. Fungal contamination of textile objects preserved in Slovene museums and religious institutions. Int. Biodeter. Biodegr. 2015, 97, 51-59. [CrossRef]

10. Caneva, G.; Nugari, M.P.; Salvadori, O. La biologia nel Restauro; Nardini Editore: Firenze, Italy, 1994.

11. Sterflinger, K.; Piñar, G. Microbial deterioration of cultural heritage and works of art-Tilting at windmills? Appl. Microbiol. Biotechnol. 2013, 97, 9637-9646. [CrossRef]

12. Valentin, N. Microbial contamination in museum collections: Organic materials. In Molecular Biology and Cultural Heritage; Saiz Jimenez, C., Ed.; Swets \& Zeitlinger: Lisse, The Netherlands, 2003; pp. 85-91.

13. Caneva, G.; Nugari, M.P.; Salvadori, O. Biology in the Conservation of Works of Art; Sintesi Grafica s.r.l.: Roma, Italy, 1991.

14. Szostak-Kotowa, J. Biodeterioration of textiles. Int. Biodeterior. Biodegrad. 2004, 53, 165-170. [CrossRef] 
15. Mukerji, K.G.; Garg, K.L.; Mishra, A.K. Fungi in deterioration of museum objects. In Proceedings of the 3rd International conference on Biodeterioration of Cultural Property, Bangkok, Thailand, 4-7 July 1995; pp. 226-241.

16. Kowalik, R. Microbiodeterioration of Library Materials. Restaurator 1980, 4, 99-114. [CrossRef]

17. Montegut, D.; Indictor, N.; Koestler, R.J. Fungal deterioration of cellulosic textiles: A review. Int. Biodeterior. Biodegrad. 1991, 28, 209-226. [CrossRef]

18. Arif Hossain, M. Investigating Bio Deterioration of Cultural Heritage: Detection and Identification of Microbial Communities and Biocides Application; University of Évora: Évora, Portugal, October 2017; Available online: https://www.academia.edu/32181292 /Investigating_bio_deterioration_of_Cultural_Heritage_Detection_and_identification_of_microbial_com-408_munities_and_ biocides_application (accessed on 10 September 2020).

19. Sterflinger, K. Fungi as geologic agents. Geomicrobiol. J. 2000, 17, 97-124. [CrossRef]

20. Vukojević, J.; Grbić, M.L. Moulds on paintings in Serbian fine art museums. Afr. J. Microbiol. Res. 2010, 4, 1453-1456.

21. Manente, S.; Micheluz, A.; Ganzerla, R.; Ravagnan, G.; Gambaro, A. Chemical and biological characterization of paper: A case study using a proposed methodological approach. Int. Biodeter. Biodegr. 2012, 74, 99-108. [CrossRef]

22. Di Carlo, E.; Barresi, G.; Palla, F. Biodeterioration. In Biotechnology and Conservation of Cultural Heritage; Palla, F., Barresi, G., Eds.; Springer: New York, NY, USA, 2017; pp. 1-32.

23. Fierascu, I.; Dima, R.; Fierascu, R.C. Natural Extracts for preventing Artefacts Biodeterioration. In Proceedings of the 17 International Conference on Cultural Heritage and New Technologies (CHNT 17, 2012), Vienna, Austria, 5-7 November 2012; Fischer Ausserer, K., Ed.; Museen der Stadt Wien-Stadtarchäologie: Vienna, Austria, 2012.

24. Pattnaik, S.; Subramanyam, V.R.; Kole, C. Antibacterial and antifungal activity of ten essential oils in vitro. Microbios 1996, 86, 237-246.

25. Abad, M.J.; Ansuategui, M.; Bermejo, P. Active antifungal substances from natural sources. ARKIVOC 2007, 7, 116-145.

26. Bayramoğlu, E.E.; Gülümser, G.; Karaboz, I. The Investigation of Antibacterial Activities of Some Essential Oils in Wet Blue Leather. Int. J. Nat. Eng. Scien. 2008, 2, 33-36.

27. Guiamet, P.S.; Gómez de Saravia, S.G.; Arenas, P.; Pérez, M.L.; De la Paz, J.; Borrego, S.F. Natural products isolated from plants used in biodeterioration control. Pharmacologyonline 2006, 3, 537-544.

28. Sasso, S.; Scrano, L.; Ventrella, E.; Bonomo, M.G.; Crescenzi, A.; Salzano, G.; Bufo, S.A. Natural biocides to prevent the microbial growth on cultural heritage. In Proceedings of the Conference Built Heritage 2013-Monitoring Conservation and Management, Milan, Italy, 18-20 November 2013; pp. 1035-1042.

29. Orlita, A. Microbial biodeterioration of leather and its control: A review. Int. Biodeter. Biodegr. 2004, 53, 157-163. [CrossRef]

30. Al-Hussaini, R.; Mahasneh, A.M. Microbial growth and quorum sensing antagonist activities of herbal plants extracts. Molecules 2009, 14, 3425-3435. [CrossRef]

31. Abdel-Maksoud, G.; El-Amin, A.-R.; Afifi, F. Insecticidal activity of Cinnamomum cassia extractions against the common Egyptian mummies' insect pest (Dermestes maculatus). Int. J. Conserv. Sci. 2014, 5, 355-368.

32. Barresi, G.; Carlo, E.; Trapani, M.R.; Parisi, M.G.; Chillè, C.; Mulè, M.F.; Cammarata, M.; Palla, F. Marine organisms as source of bioactive molecules applied in restoration projects. Herit. Sci. 2015, 3, 17-20. [CrossRef]

33. Borrego, S.; Valdés, O.; Vivar, I.; Lavin, P.; Guiamet, P.; Battistoni, P.; Gómez de Saravia, S.; Borges, P. Essential oils of plants as biocides against microorganisms isolated from Cuban and Argentine Documentary heritage. ISRN Microbiol. 2012, 826786. [CrossRef] [PubMed]

34. Warscheid, T. Integrated concepts for the protection of cultural artifacts against biodeterioration. In Of Microbes and Art, the Role of Microbial Communities in the Deterioration and Protection of Cultural Heritage; Ciferri, O., Tiano, P., Mastromei, G., Eds.; Kluwer Academic/Plenum Publishers: New York, NY, USA, 2000; pp. 185-201.

35. Calvo, M.A.; Arosemena, E.L.; Shiva, C.; Adelantado, C. Antimicrobial activity of plant natural extracts and essential oils. In Science against Microbial Pathogens: Communicating Current Research and Technological Advances; Méndez-Villas, A., Ed.; Formatex Research Center: Badajoz, Spain, 2001; pp. 1179-1185.

36. Rotolo, V.; Barresi, G.; Di Carlo, E.; Giordano, A.; Lombardo, G.; Crimi, E.; Costa, E.; Bruno, M.; Palla, F. Plant extracts as green potential strategies to control the biodeterioration of Cultural Heritage. Int. J. Conserv. Sci. 2016, 7, 839-846.

37. Ćirković, I.; Jovalekić, M.; Jegorović, B. In vitro antibacterial activity of garlic and synergism between garlic and antibacterial drugs. Arch. Biol. Sci. 2012, 64, 1369-1375. [CrossRef]

38. de la Paz, J.; Larionova, M.; Maceira, M.A.; Borrego, S.F.; Echevarría, E. Control of biodeterioration using a fraction isolated from leaves of Ricinus communis linn. Pharmacologyonline 2006, 3, 462-466.

39. Guiamet, P.S.; de la Paz, N.J.; Arenas, P.M.; Gómez de Saravia, S.G. Differential sensitivity of Bacillus sp. isolated from archive materials to plant extracts. Pharmacologyonline 2008, 3, 649-658.

40. Afifi, H.A.M. Comparative efficacy of some plant extracts against fungal deterioration of stucco ornaments in the Mihrab of Mostafa Pasha Ribate, Cairo, Egypt. Am. J. Biochem. Mol. Biol. 2012, 2, 40-47. [CrossRef]

41. Bacci, L.; Lima, J.K.A.; Araùjo, A.P.A.; Blank, A.F.; Silva, I.M.A.; Santos, A.A.; Santos, A.C.C.; Alves, P.B.; Picanço, M.C. Toxicity, behavior impairment, and repellence of essential oils from pepper-rosmarin and patchouli to termites. Entomol. Exp. Appl. 2015, 156, 66-76. [CrossRef] 
42. Stupar, M.; Grbić, M.L.J.; Džamić, A.; Unkovia, N.; Ristić, M.; Jelikić, A.; Vukojević, J. Antifungal activity of selected essential oils and biocide benzalkonium chloride against the fungi isolated from cultural heritage objects. S. Afr. J. Bot. 2014, 93, 118-124. [CrossRef]

43. Savković, Z.D.; Stupar, M.Č.; Grbić, L.M.V.; Vukojević, J.B. Comparison of anti-Aspergillus activity of Origanum vulgare L. essential oil and commercial biocide based on silver ions and hydrogen peroxide. Acta Bot. Croat. 2016, 75, 121-128. [CrossRef]

44. Bayramoglu, E. Unique biocide for the leather industry. J. Am. Leather Chem. Assoc. 2007, 102, 347-352.

45. Casiglia, S.; Bruno, M.; Scandolera, E.; Senatore, F.; Senatore, F. Influence of harvesting time on composition of essential oil of Thymus capitatus (L.) Hoffmanns. \& Link. growing wild in northern Sicily and its activity on microorganisms affecting historical art crafts. Arab. J. Chem. 2019, 12, 2704-2712. [CrossRef]

46. Soković, M.; Vukojević, J.; Marin, P.; Brkić, D.; Vajs, V.; Griensven, L.J.L.D. Chemical composition of essential oils of Thymus and Mentha species and their antifungal activities. Molecules 2009, 14, 238-249. [CrossRef]

47. Walentowska, J.; Foksowicz-Flaczyk, J. Thyme essential oil for antimicrobial protection of natural textiles. Int. Biodeter. Biodegr. 2013, 84, 407-411. [CrossRef]

48. Othman, M.; Saada, H.; Matsuda, Y. Antifungal activity of some plant extracts and essential oils against fungi-infested organic archaeological artefacts. Archaemometry 2020, 62, 187-199. [CrossRef]

49. Radwan, I.A.; Abed, A.H.; Abeer, M.R.; Ibrahim, R.A.; Abdallah, A.S. Effect of thyme, clove and cinnamon essential oils on Candida albicans and moulds isolated from different sources. Am. J. Anim. Vet. Sci. 2014, 9, 303-314. [CrossRef]

50. Stević, T.; Berić, T.; Šavikin, K.; Soković, M.; Gođevac, D.; Dimkić, I.; Stanković, S. Antifungal activity of selected essential oils against fungi isolated from medicinal plan. Ind. Crop. Prod. 2014, 55, 116-122. [CrossRef]

51. Širvaitytè, J.; Šiugždaitè, J.; Valeika, V. Application of commercial essential oils of Eucalyptus and Lavender as natural preservative for leather tanning industry. Rev. Chim. 2011, 62, 884-893.

52. Al-Bayati, F.A. Synergistic antibacterial activity between Thymus vulgaris and Pimpinella anisum essential oils and methanol extracts. J. Ethnopharmacol. 2007, 116, 403-406. [CrossRef]

53. EL-Hefny, M.; Abo Elgat, W.A.; Al-Huqail, A.A.; Ali, H.M. Essential and Recovery Oils from Matricaria chamomilla Flowers as Environmentally Friendly Fungicides Against Four Fungi Isolated from Cultural Heritage Objects. Processes 2019 , 7, 809. [CrossRef]

54. Mahilrajan, S.; Nandakumar, J.; Kailayalingam, R.; Manoharan, N.A.; SriVijeindran, S. Screening the antifungal activity of essential oils against decay fungi from palmyrah leaf handicrafts. Biol. Res. 2014, 47, 35. [CrossRef]

55. Pepa, T.D.; Elshafie, H.S.; Capasso, R.; De Feo, V.; Camele, I.; Nazzaro, F.; Scognamiglio, M.R.; Caputo, L. Antimicrobial and Phytotoxic Activity of Origanum heracleoticum and O. majorana Essential Oils Growing in Cilento (Southern Italy). Molecules 2019, 24, 2576. [CrossRef]

56. Palla, F.; Bruno, M.; Mercurio, F.; Tantillo, A.; Rotolo, V. Essential Oils as Natural Biocides in Conservation of Cultural Heritage. Molecules 2020, 25, 730. [CrossRef] [PubMed]

57. Chirila, C.; Berechet, M.D.; Deselnicu, V. Thyme essential oil as natural leather preservative against fungi. Int. Conf. Adv. Mater. Syst. 2016, 132268064. [CrossRef]

58. Deselnicu, V.; Maier, S.S.; Albu, L.; Buruntea, N. Antimicrobial and Antifungal Leathers for Increasing the Health and the Comfort of the Individuals. In Proceedings of the CORTEP 2007, Iasi, Romania, 18-21 October 2007.

59. Berechet, M.D.; Chirila, C.; Deselnicu, V. Antifungal Activity of Thyme Essential Oil on Woolen Sheepskins. In Proceedings of the 6th International Conference on Advanced Materials and Systems-ICAMS 2016, Bucharest, Romania, 20-23 October 2016; pp. 203-208. [CrossRef]

60. Niculescu, O.; Leca, M.; Moldovan, Z.; Deselnicu, D.C. Obtaining and characterizing of a product with antifungal properties based on essential oils and natural waxes for finishing natural leathers. Rev. Chim. 2015, 66, 1733-1736.

61. Niculescu, O.; Gaidau, C.; Simon, D.; Berechet, M.D. The Study on the Possibility of Using Ecological Materials with Antifungal Properties for Treating Natural Leathers. Rev. Chim. 2020, 71, 445-449. [CrossRef]

62. Marcu, F.; Ilieș, D.C.; Wendt, A.J.; Indrie, L.; Ilies, A.; Burta, L.; Caciora, T.; Herman, G.V.; Todoran, A.; Baias, S.; et al. Investigations regarding the biodegradation of cultural heritage. Case study of traditional embroidered peasant shirt (Maramures, Romania). Rom. Biotechnol. Lett. 2020, 25, 1362-1368. [CrossRef]

63. Ilies, A.; Hurley, P.D.; Ilies, D.C.; Baias, S. Tourist animation-A chance adding value to traditional heritage: Case study in the Land of Maramures (Romania). Rev. Etnogr. Si Folc. 2017, 1-2, 131-151.

64. Ilies, A.; Grama, V. The external western Balkan border of the European Union and its borderland: Premises for building functional transborder territorial systems. Ann. Anal. Za Istrske Mediter. Studije-Ser. Hist. Et Sociol. 2010, 20, 457-468.

65. Wei, Q.F.; Wang, X.Q.; Mather, R.R.; Fotheringham, A.F. New Approaches to Characterisation of Textile Materials Using Environmental Scanning Electron Microscope. Fibres Text. East. Eur. 2004, 12, 79-83.

66. Ilieș, D.C.; Indrie, L.; Ilieș, A.; Marcu, F.; Axinte, A.; Burtă, L.; Herman, G.V.; Atasoy, E.; Baidog, A.; Iovan, C.; et al. Investigations of aged textiles using scanning electron microscopy. J. Environ. Biol. 2020, 41, 499-504. [CrossRef]

67. Dezsi, S.; Rusu, R.; Ilies, M.; Ilies, G.; Badarau, A.S.; Rosian, G. The role of rural tourism in the social and economic revitalisation of Lapus land (Maramures County, Romania). Proc. Pap. Geoconference Ecol. Econ. Educ. Legis. 2014, 2, 783-790.

68. Deac, L.A.; Gozner, M.; Sambou, A. Ethnographic museums in the rural areas of Crișana region, Romania-keepers of local heritage, tradition and lifestyle. GeoJournal Tour. Geosites 2019, 27, 1251-1260. [CrossRef] 
69. Wendt, J.A.; Ilieş, A.; Wiskulski, T.; Ilieş, M. Wooden orthodox churches in the Maramureş Region-opportunities and threats of tourism. Ekonom. Prob. Tur. 2018, 43, 133-140. [CrossRef]

70. Indrie, L.; Zlatev, Z.; Ilies, D.C.; Sturza, A.; Dochia, M.; Gozner, M.; Herman, G.; Caciora, T. Implementation of image processing techniques as a tool for form analysis of Romanian folk elements. Ind. Text. 2020, 71, 492-498. [CrossRef]

71. Adam, K.; Sivropoulu, A.; Kokkini, S.; Lanaras, T.; Arsenakis, M. Antifungal activities of Origanum vulgare subsp. hirtum, Mentha spicata, Lavandula angustifolia and Salvia fruticosa essential oils against human pathogenic fungi. J. Agric. Food Chem. 1998, 46, 1739-1745. [CrossRef]

72. Daferera, D.J.; Ziogas, B.N.; Polissiou, M.G. The effectiveness of plant essential oils on the growth of Botrytis cinerea, Fusarium sp. and Clavibacter michiganensis subsp. michiganensis. Crop Prot. 2003, 22, 39-44. [CrossRef]

73. Behmanesh, F.; Pasha, H.; Sefidgar, A.A.; Taghizadeh, M.; Moghadamnia, A.A.; Adib Rad, H.; Shirkhani, L. Antifungal Effect of Lavender Essential Oil (Lavandula angustifolia) and Clotrimazole on Candida albicans: An in Vitro Study. Scientifica 2015, 1-5. [CrossRef] [PubMed]

74. Ghoorchibeigi, M.; Larijani, K.; Aberoomand Azar, P.; Zare, K.; Mehregan, I. Chemical composition and radical scavenging activity of Citrus limon peel essential oil Orient. J. Chem. 2017, 33, 458-461. [CrossRef]

75. Griffin, S.G.; Markham, J.L.; Leach, D.N. An agar dilution method for the determination of the minimum inhibitory concentration of essential oils. J. Essent. Oil Res. 1999, 12, 249-255. [CrossRef]

76. Lee, T.K.; Nguyen, T.T.H.; Le, T.T.T. Antifungal activity of the tea tree essential oils (Melaleuca alternofolia) against pathogenic fungi. Int. J. Adv. Res. 2019, 7, 1239-1248. [CrossRef]

77. Rushton, R.T.; Davis, N.W.; Page, J.C.; Durkin, C.A. The effect of tea tree oil extract on the growth of fungi. Low. Extrem. 1997, 4, 113-116.

78. Nenoff, P.; Haustein, U.F.; Brandt, W. Antifungal activity of the essential oil of Melaleuca alternifolia (tea tree oil) against pathogenic fungi in vitro. Ski. Pharmacol. 1996, 9, 388-394. [CrossRef]

79. Carson, C.F.; Riley, T.V. Antimicrobial activity of the major components of the essential oil of Melaleuca alternifolia. J. Appl. Bacteriol. 1995, 78, 264-269. [CrossRef]

80. Procop, G.W.; Church, D.L.; Hall, G.S.; Janda, W.M.; Koneman, E.W.; Schreckenberger, P.C.; Woods, G.L. Koneman's Color Atlas and Textbook of Diagnostic Microbiology, 7th ed.; Wolters Kluwer: Alpen, The Netherlands, 2016.

81. Buiuc, D.; Negut, M. Tratat de Microbiologie Clinică, 3rd ed.; Editura Medicală: Bucuresti, Romania, 2009.

82. Sil, A.; Pramanik, K.; Samantaray, P.; Firoz, M.; Yadav, V. Essential oils: A boon towards eco-friendly management of phytopathogenic fungi. J. Entomol. Zool. Stud. 2020, 8, 1884-1891.

83. Bielak, E.; Marcinkowska, E.; Sygula-Cholewinska, J. The Durability of Antimicrobial Effect of Leathers Finished with Oregano Oil. J. Am. Leather Chem. Assoc. 2017, 112, 377-386.

84. Özcan, M.M.; Starovic, M.; Aleksic, G.; Figueredo, G.; Juhaimi, F.A.; Chalchat, J.-C. Chemical Composition and Antifungal Activity of Lavender (Lavandula stoechas) Oil. Nat. Prod. Commun. 2018, 13, 895-898. [CrossRef]

85. Smigielski, K.; Prusinowska, R.; Stobiecka, A.; Kunicka-Styczyñska, A.; Gruska, R. Biological Properties and Chemical Composition of Essential Oils from Flowers and Aerial Parts of Lavender (Lavandula angustifolia). J. Essent. Oil Bear. Plants 2018, 21, 1303-1314. [CrossRef]

86. Bazaz, R.; Denning, D.W. Aspergillosis: Causes, types and treatment. Pharm. J. 2019, 303, 7927. [CrossRef]

87. Paul, D.; Paul, K. Aspergillosis: An overview. IJPSR 2018, 9, 5032-5049. [CrossRef]

88. Pop, O.L.; Judea Pusta, C.T.J.; Buhas, C.L.; Judea, A.S.; Huniadi, A.; Jurca, C.; Sandor, M.; Negrutiu, B.M.; Buhas, B.A.; Nikin, Z.; et al. Anaplastic Lymphoma Kinase (ALK) Overexpression in Lung Cancer Biopsies-An 18 month study in north western Romania. Rev. Chim. 2019, 70, 2690-2693. [CrossRef]

89. Girmenia, C.; Pizzarelli, G.; Cristini, F.; Barchiesi, F.; Spreghini, E.; Scalise, G.; Martino, P. Candida guilliermondii Fungemia in Patients with Hematologic Malignancies. J. Clin. Microbiol. 2006, 44, 2458-2464. [CrossRef] [PubMed]

90. Katotomichelakis, M.; Nikolaidis, C.; Makris, M.; Proimos, E.; Constantinidis, T.C.; Papadakis, C.E.; Danielides, V. Alternaria and Cladosporium calendar of Western Thrace: Relationship with allergic rhinitis symptoms. Laryngoscope 2016, 126, E51-E56. [CrossRef]

91. Sandoval-Denis, M.; Sutton, D.A.; Martin-Vicente, A.; Cano-Lira, J.F.; Wiederhold, N.; Guarro, J.; Genéa, J. Cladosporium Species Recovered from Clinical Samples in the United States. J. Clin. Microbiol. 2015, 53, 2990-3000. [CrossRef]

92. Huniadi, A.; Sorian, A.; Maghiar, A.; Mocuta, D.; Antal, L.; Pop, O.L.; Judea Pusta, C.T.; Buhas, C.L.; Pascalau, A.; Sandor, M. 6 (2, 3-Dichlorodiphenyl)-1, 2, 4-Triazine-3, 5-Diamine Use in Pregnancy and Body Stalk Anomaly-A Possible Association? Rev. Chim. 2019, 7, 2656-2659. [CrossRef]

93. Visagie, C.M.; Hirooka, Y.; Tanney, J.B.; Whitfield, E.; Mwange, K.; Meijer, M.; Amend, A.S.; Seifert, K.A.; Samson, R.A. Aspergillus, Penicillium and Talaromyces isolated from house dust samples collected around the world. Stud. Mycol. 2014, 78, 63-139. [CrossRef] [PubMed]

94. Hu, Y.; Zhang, J.; Li, X.; Yang, Y.; Zhang, Y.; Ma, J.; Xi, L. Penicillium marneffei Infection: An Emerging Disease in Mainland China. Mycopathologia 2013, 175, 57-67. [CrossRef] [PubMed] 